\title{
School Mathematics and miyō-pimōhtēwin
}

\author{
Stavros Georgios Stavrou \\ University of Saskatchewan \\ M. Shaun Murphy \\ University of Saskatchewan
}

\begin{abstract}
:
We want mathematics to be a process of miyō-pimōhtēwin (walking in a good way). Using a narrative inquiry methodology, we share our experiences working alongside two Cree elementary school teachers and the students in their mathematics classroom. The teachers taught principles that balance kohtawān (our spiritual being) and make curriculum into a relational space. The principles invite school mathematics to be learned and taught in a way that foregrounds self-awareness, doing things properly, learning new ways, being thankful, being humble, leaving problems behind you, helping yourself and keeping trying. This paper also demonstrates a promising practice of Indigenization in the mathematics classroom by providing a contextual way in which Cree students and teachers engaged in school mathematics in relational ways.
\end{abstract}

Keywords: Indigenous mathematics education; Aboriginal education; school mathematics; narrative inquiry; miyō-pimōhtēwin 


\section{Les mathématiques à l'école et miyō-pimōhtēwin}

\section{Résumé :}

Nous voulons que les mathématiques soient un processus de miyō-pimōhtē win (marcher dans la bonne direction). S'appuyant sur une méthodologie d'enquête narrative, nous partageons nos expériences de travail aux côtés de deux enseignants cris de l'école primaire et des élèves dans leur classe de mathématiques. Les enseignants ont dispensé des principes qui équilibrent kohtawān (notre bien-être spirituel) et font du programme scolaire un espace relationnel. Ces principes invitent à apprendre et à enseigner les mathématiques scolaires d'une manière qui met l'accent sur la conscience de soi, le fait de faire les choses correctement, d'apprendre de nouvelles façons, d'être reconnaissant, d'être humble, de laisser les problèmes derrière soi, de s'aider soi-même et de continuer à essayer. Cet article démontre également une pratique prometteuse d'autochtonisation dans la classe de mathématiques en fournissant une manière contextuelle dans laquelle les élèves cris et les enseignants sont engagés dans les mathématiques scolaires de manières relationnelles.

Mots clés : enseignement des mathématiques aux autochtones; éducation des autochtones; mathématiques à l'école; recherche narrative; miyō-pimōhtēwin 


\section{Greetings and Notes Terminology}

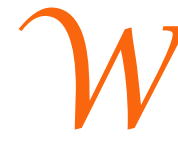

e begin by acknowledging that we live and work on Treaty 6 territory and the homeland of the Métis peoples.

My name (first author) is Stavros Stavrou. I have White settler identity with Greek heritage on my father's side, and French and Ukrainian heritage on my mother's. I teach and do research in the areas of mathematics and mathematics education. This article is based on my completed doctoral research, and it contains excerpts in my first-person voice.

My name (second author) is M. Shaun Murphy and I am White with settler ancestry. I am a professor in Educational foundations, where Stavros did his PhD work. I was his research supervisor and a collaborator in this research.

In Canada, the words Indigenous and Aborigina/ represent complex relationships between the Canadian state and its original inhabitants, and so it is important to differentiate between these terms. According to Plains Cree and Saulteaux scholar Maggie Kovach (2010), the word Indigenous refers to the first peoples of a place and their cultures, and the term Aborigina/ refers to the Indigenous peoples of Canada. Moreover, the word Aboriginal is a colonial term that was introduced in the Canadian constitution and so it is not necessarily the preferred term for some since it represents an imposed name. For this reason, the Cree teachers and students in this paper prefer the

term Indigenous. However, some of the literature we draw upon is written by academics who refer to themselves as Aboriginal. Thus, we will switch between Indigenous and Aboriginal (and refer to specific cultures, such as Cree, to disrupt pan-Indigenous/Aboriginal identity) to reflect and respect how people have chosen to identify themselves.

Stavros's doctoral research explored experiences teaching school mathematics with considerations of Indigenization. Broad in scope and practice, Indigenization includes features such as reconciliation, decolonization, language reclamation and cultural inclusion (Gaudry \& Lorenz, 2018; Stavrou, 2020). Indigenization encompasses processes that support and acknowledge Indigenous pedagogies, epistemologies, ontologies, treaty rights, sovereignty and land stewardship, as well as identify and rectify racist and colonial practices that denigrate Indigenous peoples and their knowledge systems (Battiste, 2013; Battiste \& Henderson, 2009; Brake, 2019; Korteweg \& Russell, 2012; Kovach 2010a, 2010b; Kuokkanen, 2008; Truth and Reconciliation Commission, 2015; Wildcat, 2001).

\section{Research Wonder and Principles}

We want mathematics to be a process of miyō-pimōhtēwin-walking in a good way. This paper highlights two Cree elementary school teachers (pseudonyms are Miss Moore and Miss Scribe) in a Cree-bilingual school who co-teach school mathematics with Stavros (the researcher) to their predominantly Cree sixth-grade students. The teachers taught principles that balance kohtawān (our spiritual being) and make curriculum into a relational space. Within these principles, there is an emphasis on the following: doing things properly; learning new ways; being thankful; being humble; 
leaving problems behind you; helping yourself; and keeping trying. The principles are enacted in stories to live by in which school mathematics is learned and taught in a way that foregrounds selfawareness.

Doing things properly is a moral/ethical dimension, not a procedural understanding of mathematics. Leaving problems behind you pertains to our daily struggles, not the struggles related to problem-solving in mathematics. These principles are Cree ways of being, learned from the classroom teachers, which provide teaching supports in the mathematics classroom for the students and Stavros.

Stavros's narrative inquiry research is motivated by this wondering: How do the experiences of Cree school teachers and a White Euro-Western mathematician shape the learning of school mathematics as we co-teach predominantly Cree children? By embodying the kohtawān principles, we make mathematics a process of miyō-pimōhtēwin by situating the learning of mathematical content in ways that privilege relationships. This paper also serves to demonstrate promising practices of Indigenization in the mathematics classroom by providing a contextual way in which Cree students and teachers engage in school mathematics in relational ways.

\section{Narrative Inquiry}

John Dewey (1938/1997) considered experience and education to be entwined through three criteria: continuity, interaction and situation. He explained continuity of experience to mean that "every experience both takes up something from those which have gone before and modifies in some way the quality of those which come after" (p. 35). He argued that since experiences influence the quality of further experiences, they are either educative if they lead to further growth, or miseducative if they disrupt growth. Dewey (1938/1997) stated that our knowledge from experiences informs our interactions, which are carried out through objective conditions (actions that are in the power of the educator to regulate) and internal conditions (knowledge that comes from experience). Taking the objective and internal conditions together gives the third criterion called a situation. Dewey (1938/1997) explained that living in a world means living in a series of situations, and thus "the conceptions of situation and interaction are inseparable from each other. An experience is always what it is because of a transaction taking place between an individual and what, at the time, constitutes [their] environment" (p. 43). A Deweyan ontology of pragmatism (qua social constructivism) provides the foundation of narrative inquiry, which is methodology attentive to narrative understanding of experience.

Clandinin and Caine (2013) explained that narrative inquiry is both a way to view experience and a methodology for inquiring into experience. Clandinin and Connelly (2000) considered narrative inquiry as research into experience through a movement within a three-dimensional inquiry space in which temporality, sociality and place represent each dimension. Thus, a touchstone of narrative inquiry is representing experiences in ways that show temporality, sociality and place. These narrative commonplaces are founded on Dewey's (1938/1997) epistemological and ontological terms of continuity, situation and interaction. Continuity of experience informs the temporal considerations of 
past, present and future. Interaction informs the personal and social contexts of sociality. Situation informs the narrative backdrop of place in which the experiences unfold (Clandinin \& Connelly, 2000).

Researchers also move inward to the internal conditions of "feelings, hopes, aesthetic reactions, and moral dispositions" (Clandinin \& Connelly, 2000, p. 50), outward toward the existential conditions of the environment and place, as well as backward and forward in time when attending to the continuum of experiences. Clandinin and Connelly (2000) stated that doing research into an experience means experiencing an experience in the inward, outward, forward and backward directions and asking questions along each direction. This view of narrative inquiry as the study of experience over time and in contexts makes it both a way to view phenomena and a research methodology (Caine et al., 2013).

Clandinin and Murphy (2009) explained that it is through relational, temporal and continuous understandings of reality that researchers and participants can conceive how reality can be known. Situating experiences as sites of knowledge and then inquiring into those experiences generates new understandings between the observer and their surroundings (Clandinin \& Murphy, 2009; Clandinin \& Rosiek, 2007).

\section{Situating the Inquiry}

Miss Moore and Miss Scribe are Cree women who teach sixth-grade students at a Creebilingual elementary school located in a western Canadian prairie province. Over a three-year period, Miss Moore and Miss Scribe were two of three ongoing participants in Stavros's narrative inquiry research. Once a week for an hour, Miss Moore and Miss Scribe combined their Grade 6 students into one class, and Stavros visited the teachers' classroom to co-teach mathematics. Between both teachers, there were around 30 students in the class, all of whom identified as Cree. Following the hour-long class each week, Stavros interviewed Miss Moore and Miss Scribe together for an hour over lunch. He composed field notes through these interviews and then negotiated with Miss Moore and Miss Scribe how these field notes would be represented in the interim and final research texts.

Their classroom lessons were mindful of provincial curriculum guides that described the importance of having an awareness of students' cultural context and the pedagogical practices that influence the success of Indigenous students in the mathematics classroom (Saskatchewan Ministry of Education, Curriculum E-Learning, Science Technology Unit., 2009). Since the curriculum and the literature on Indigenizing school mathematics is limited in scope, there are no consistent conceptualizations of how this process might unfold in the classroom. However, Indigenization revealed itself in one possibility through the experiences of the Cree teachers and students. Indeed, Miss Moore and Miss Scribe's teaching practice provided new understandings that Indigenizing school mathematics does not necessarily involve mathematical content, rather it considered how we might engage with the content and each other.

Beginning in relationship before engaging in school mathematics demonstrated that effective classroom teaching is more than just emphasizing curriculum content. Miss Moore and Miss Scribe 
situated the curriculum content into processes such as having an awareness of oneself and others, having gratitude, being open to learning new things in a proper way and having perseverance when learning. This way of being in the classroom is called miyō-pimōhtēwin, which is Cree for walking in a good way. Walking in a good way occurs when we are mindful of our spiritual being through eight kohtawān principles, which we will discuss in this paper.

\section{Kohtawān Principles: Mathematical Tools as Learning Supports}

There are a number of broad mathematical tools that facilitate learning in a mathematics classroom. Bruner (1966) explained that mathematical tools are "amplifiers of human capacities" (p. 81) and generally include oral language, written symbols, materials, manipulatives and acquired skills of students (Hiebert et al., 1997). As an extension of this, mathematical language (and language, generally) as a mathematical facilitator (tool) is meant to make learning easier by providing a way to communicate ideas verbally and through written symbols. Materials and manipulatives can be used to represent abstract concepts concretely. Building on skills that students already possess is a pedagogical practice that acknowledges their unique experiences.

A prominent feature of Miss Moore and Miss Scribe's mathematics classroom was the way they taught through Cree ways of being while doing Euro-Western school mathematics. The students were called upon to solve problems, explain their reasoning to the class and reflect upon their strategies with an understanding that, as participants in the classroom, we were always mindful of the spiritual being that guides our interactions so that we were miyō-pimōhtēwin. The teachers explained that we walk in a good way by embodying eight kohtawān principles. An image of the kohtawān principles is in the following field note.

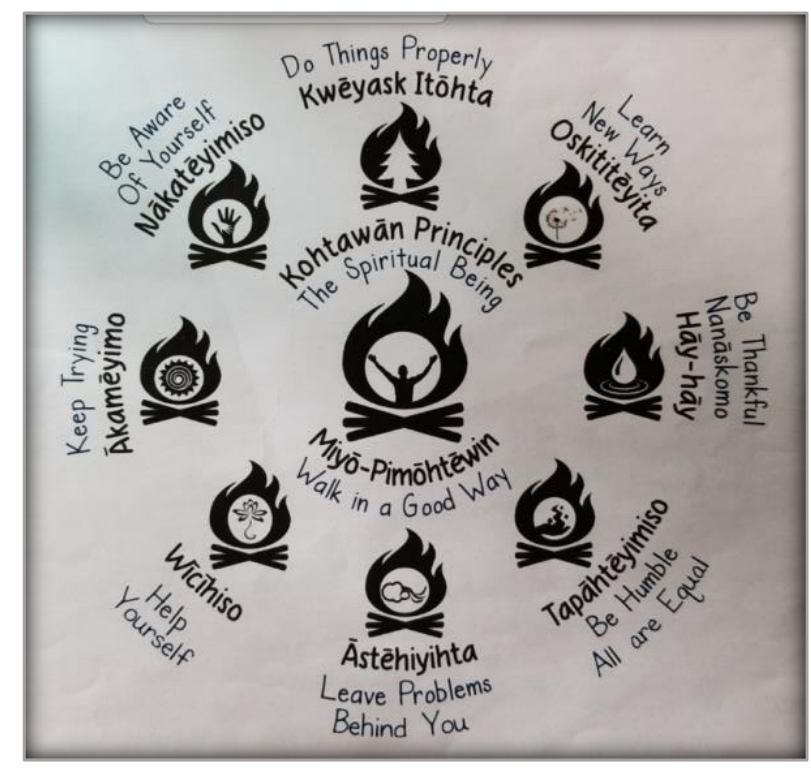

Eight kohtawān principles. Classroom handout, December 2017. Created by Senapan Thunder. Used with permission. 
Stavros saw that the kohtawān principles supported learning in Miss Moore and Miss Scribe's mathematics classroom. They created a relational space by exemplifying the Cree norm miyōpimōhtē win so that mathematical learning was not just about teaching the content through written symbols, discussing problems and using manipulatives-it was about learning the content in a good way.

\section{Kohtawān Principles and Cree Ways of Being}

Indigenous ways of knowing and being are rooted in collective histories, experiences, values and knowledges of distinct and diverse Indigenous cultures (Deer, 2013). Indigenous epistemologies and ontologies are narrated through Indigenous languages, situated in specific geographic contexts and are enacted through Elder-guided ceremonial traditions and other social interactions (Battiste, 2013; Mitchell, 2005). Indigenous ways of knowing and being are shared through oral traditions of storytelling and protocols that foreground community practices of doing things in a good way (Kovach, 2010b).

Cree ways of being were linguistically described by Miss Moore and Miss Scribe through the phrase miyō-pimōhtēwin. This was embodied by Miss Moore and Miss Scribe through kohtawān principles. Following one particular class in December of 2017, Stavros had an interview with Miss Moore and Miss Scribe. They explained that the principles are a state of being that invites them to feel balanced and nākatèyimiso (being aware of yourself). Miss Scribe brought up a lesson in which she asked her students to share a story that used multiplication in some way. She explained that one student, Jasmine (pseudonym) ${ }^{1}$, told a story about baking with her kokohm (grandma). Jasmine said they baked 24 cookies and subtracted the amount she and her brothers ate. A classmate interrupted her story because he thought that talking about subtraction was 'too easy'. Miss Scribe saw that the comment broke Jasmine's confidence and used that experience as a learning opportunity to remind everyone that no one's ideas and stories are better than others'. She used the word tapāhtēyimisoall are equal. (Summary of interview conversation, December 2017).

The kohtawān principles represented a way of being that nourished the spiritual self through self-awareness, doing things properly, learning new ways, being thankful, being humble, leaving problems behind you, helping yourself and keeping trying. Being mindful of these processes is how we walk in a good way.

\section{The Role of a Teacher}

The ways Miss Moore and Miss Scribe related with their students spoke to their perception of what their roles were as teachers. When the students gathered in the classroom for mathematics, Miss Moore and Miss Scribe attended to how the students were interacting with each other. Recess disagreements between students were settled and everyone was reminded to transition from their recess behavior to their classroom behavior, which they understood to mean walking and speaking

\footnotetext{
${ }^{1}$ All pseudonyms were chosen by the participants.
} 
quietly instead of running and shouting. For the teachers and students, this was part of getting ready to do mathematics and any other school work. Miss Moore and Miss Scribe continued to attend to how the students interacted with each other and the content during the lesson.

During a week in December before the holiday break, Stavros visited Miss Moore and Miss Scribe. They wanted to teach the process of multiplying a two-digit whole number with another twodigit whole number (such as $12 \times 48$ ). They already introduced the students to the stacking method, in which the numbers being multiplied are written on top of each other so that the digits line up based on their place value. Miss Moore and Miss Scribe asked Stavros to present other methods the students could use to multiply. Stavros asked the students to sit in partners and gave each pair Dry Erase markers and a laminated paper to write their answers on. As he was distributing supplies, a few students started drawing pictures and scribbling on the paper and on each other. Miss Scribe guided the students to stop "fooling around and wait for instructions" using the phrase kwēyask itōhta-do things correctly.

After Stavros demonstrated on the board a few examples of multiplication using the grid method, he provided an exercise for the students to work out on their laminated papers. Miss Moore, Miss Scribe and Stavros walked around the room as the students worked in partners. A student named Patrick (pseudonym) raised his hand because he was unsure of how to get started. He was frustrated as he rewrote his problem several times, until eventually he looked over at the groups working beside him to confirm if he was on the right track. Miss Moore commended him for seeking guidance from his classmates by learning from watching, which she called kiskinowâpahkêw. As the students worked through the problems they were reminded to keep trying-äkaméyimo. At the end of the lesson, Stavros walked around to collect his supplies. The students began chatting and getting their lunch. Miss Moore and Miss Scribe reminded the students to thank him: "Hāy-hāy! Nanāskomowin, we are thankful to Mr. Stavrou for coming to share with us. When he shares his math knowledge with us we learn new ways together. Oskititētiya." (Field note, December 2017).

The roles of Miss Moore and Miss Scribe were to create a classroom in which students were doing things in a good way. As the students engaged in the mathematics lesson for the day, there were tensions from the students as they learned the concepts. As in every classroom, some students struggled more than others, and so it was the role of the teacher to provide tools that facilitated learning. This was achieved by enacting the kohtawān principles which ensured miyō-pimōhtē win, so that the mathematics classroom remained a place of loving kindness. In the example of Patrick looking over at his classmates' work to help get himself on track, Miss Moore did not call this cheating. Rather, she applauded his efforts to learn from what his classmates were doing, showing that learning with the support of classroom community is also an act of kindness.

\section{Tensions When the Kohtawān Principles are Not Practiced}

Educators face tensions as they interact with their students throughout the day. Attending to the varied needs of the students is necessary but demanding work. There are times when educators may feel like their cup is only half full. The kohtawān principles are a mindfulness that attends to self- 
awareness, doing things properly, learning new ways, being thankful and humble, leaving problems behind you, helping yourself and keep trying.

In the following field note, Stavros retold a lesson filled with tensions that arose from work stresses. Prior to attending Miss Moore and Miss Scribe's classroom, he was teaching an undergraduate calculus course that had 300 students registered in the course. On the particular day described in the field note below, he left the lecture feeling worn out because his calculus students were chattier than usual, likely because it was Friday before the midterm break. His experience with Miss Moore, Miss Scribe and their students became an educative experience (Dewey, 1938/1997) as he learned new ways of being during times of tension. The field note is told in Stavros's first person voice.

When I arrived at Miss Moore and Miss Scribe's classroom, some students were not their usual excited selves. I turned on the SMART board at the front of the room and loaded a math game related to working with fractions. After I demonstrated the activity, Miss Moore and Miss Scribe passed around tablets for the students to play the fraction game on. Normally, the students require almost no prompting when it comes to activities using the tablets, but today was different. I observed a few students either not using their tablets or going to websites other than the one they were told. Admittedly, after a long week and coming from a noisy university lecture, I did not have much patience. Miss Scribe caught on to this right away and interjected to get the students on track. The students whom I observed looking down vacantly at their desks continued to do this. I was surprised to see their mood unchanged after being given tablets to play with. Miss Moore discretely explained that a few of the students had an argument during recess. I caught myself rolling my eyes. I was annoyed their disinterest in my activity. Coming from my loud lecture, the chattiness from some of the grade six students was also feeding my negative mood. I looked at the clock wishing lunch time would come sooner. (Field note, February 2018)

As Stavros reflected on the tensions of that particular day, it was obvious the experience was mis-educative because he did not pause to reflect the feeling of imbalance he was facing as he transitioned from his university lecture to the grade six classroom. Certainly some of the students were also facing this, and it was a failure on his part not to slow down and check-in with himself. He was not mindful of àstēhiyihta_leaving his problems behind. He came into Miss Moore and Miss Scribe's classroom feeling the stress from the calculus lecture he was coming from. He knew he was feeling imbalanced as he walked in the sixth-grade classroom, but did not attend to that, and it resulted in a sub-par lesson with some of the students. The students who were feeling upset from their recess argument would have also benefited from àstēhiyihta.

The following week, he used the driving time between his university lecture and classroom session to practice āstēhiyihta. While his day had been going smoothly, there were things that tumbled around his mind throughout the day, and so practicing àstēhiyihta involved leaving even the smallest issues behind. The following field note is told in Stavros's first person voice. 
As I drove to my lesson, I recalled how poorly the previous week went. I felt empowered to do better as I reminded myself to be aware-nākatēyimiso. I always hope I bring something valuable for Miss Moore, Miss Scribe and their sixth-grade students when I come to our sessions. I am learning new tools to teach mathematics. Oskititēyita is to learn new ways of being that centre our spiritual selves.

When I walked into the classroom, the students were excited to see me and asked me what activities I brought. As I passed out supplies, Jake (pseudonym) asked, "Are you going on a date later?" To which I curiously replied, "No, what makes you ask that?" Jake giggled, "You're wearing cologne. My older brother always wears cologne when he's going to smooch his girlfriend!" The class erupted in laughter, and the lesson proceeded from there. (Field note, February 2018)

Stavros learned that it takes everyone-him, the teachers and the students-to make a classroom a place of miyō-pimōhtēwin. Walking in a good way required nourishing our whole selves through the kohtawā $n$ principles and demonstrated how the mathematics classroom could be a place of flourishing.

\section{Moving Forward}

In Stavros's experiences working with teachers, administrators, school boards and contentdevelopers for the curriculum, Euro-Western perspectives of Indigenization privileges content, which often takes the form of over-simplified cultural phenomena incongruently placed as an aside to Euro-Western school mathematics (Stavrou \& Miller, 2017). Stavros's research showed that Indigenizing school mathematics can be taken up as centring ways of being. In this way, school mathematics is not just about the content, but about the relationships involved in learning and doing mathematics in a good way.

Further research would uncover the role of conceptual understanding of school mathematics in relation to Cree ways of knowing and being. Making a space for this is essential in moving forward initiatives related to Indigenization. This would address practices of curriculum-making in school mathematics that are centred on relationships and experience.

\section{References}

Battiste, M. (2013). Decolonizing education: Nourishing the learning spirit. University of British Columbia Press.

Battiste, M., \& Henderson, J. Y. (2009). Naturalizing Indigenous knowledge in Eurocentric education. Canadian Journal of Native Education, 32(1), 5-18.

Brake, J. (2019, February). Canada unveils Indigenous languages bill to fanfare, criticism. ATPN News. https://aptnnews.ca/2019/02/05/canada-unveils-indigenous-languages-bill-to-fanfarecriticism/

Bruner, J. S. (1966). Toward a theory of instruction. Harvard University Press. 
Caine, V., Estefan, A., \& Clandinin, D. J. (2013). A return to methodological commitment: Reflections on narrative inquiry. Scandinavian Journal of Educational Research, 57(6), 574-586. https://doi.org/10.1080/00313831.2013.798833

Clandinin, D. J., \& Caine, V. (2013). Narrative Inquiry. In A. Trainor \& E. Graue (Eds.), Reviewing qualitative research in the social sciences (pp. 166-179). Routledge.

Clandinin, D. J., \& Connelly, F. M. (2000). Narrative inquiry: Experience and story in qualitative research. Jossey-Bass.

Clandinin, D. J., \& Murphy, M. S. (2009). Relational ontological commitments in narrative research. Educational Researcher, 38(8), 598-602. https://doi.org/10.3102/0013189X09353940

Clandinin, D. J., \& Rosiek, J. (2007). Mapping a landscape of narrative inquiry: Borderland spaces and tensions. In D. J. Clandinin (Ed.), Handbook of narrative inquiry: Mapping a methodology (pp. 35-75). Sage.

Deer, F. (2013). Integrating Aboriginal perspectives in education: Perceptions of pre-service teachers. Canadian Journal of Education, 36(2), 175-211.

Dewey, J. (1997). Experience and education. Touchstone. (Original work published 1938)

Gaudry, A., \& Lorenz, D. (2018). Indigenization as inclusion, reconciliation, and decolonization: Navigating the different visions for indigenizing the Canadian academy. AlterNative: An International Journal of Indigenous Peoples, 14(13), 218-227. https://doi.org/10. $1177 / 1177180118785382$

Hiebert, J., Carpenter, T. P., Fennema, E., Fuson, K. C., Wearne, D., Murray, H., Olivier, A., \& Human, P. (1997). Making sense: Teaching and learning mathematics with understanding. Heinemann.

Korteweg, L., \& Russell, C. (2012). Decolonizing + Indigenizing = Moving environmental education towards reconciliation. Canadian Journal of Environmental Education, 17, 5-14. https://cjee.lake headu.ca/article/view/1226/642

Kovach, M. E. (2010a). Indigenous methodologies: Characteristics, conversations, and contexts. University of Toronto Press.

Kovach, M. (2010b). Conversational method in Indigenous research. First Peoples Child \& Family Review, 5(1), 40-48. https://fpcfr.com/index.php/FPCFR/article/view/172/141

Kuokkanen, R. (2007). Reshaping the university: Responsibility, Indigenous epistemes, and the logic of the gift. University of British Columbia Press.

Mitchell, H. (2005). Nehithawak of Reindeer Lake, Canada: Worldview, epistemology and relationships with the natural world. Australian Journal of Indigenous Education, 34, 33-43. https://doi.org/ $10.1017 / \mathrm{S} 132601110000394 \mathrm{X}$

Saskatchewan Ministry of Education, Curriculum E-Learning, Science Technology Unit. (2009). Mathematics 6 [Curriculum guide]. Saskatchewan Ministry of Education. https://curriculum. nesd.ca/Curriculum\%20Documents/Math\%206\%20CD.pdf

Stavrou, S. G., \& Miller, D. (2017). Miscalculations: Decolonizing and anti-oppressive discourses in indigenous mathematics education. Canadian Journal of Education, 40(3), 92-122.

https://journals.sfu.ca/cje/index.php/cje-rce/article/view/2382 
Truth and Reconciliation Commission. (2015). Honouring the truth, reconciling for the future: Summary of the final report of the Truth and Reconciliation Commission of Canada. Library and Archives Canada. http://www.trc.ca/assets/pdf/Honouring_the_Truth_Reconciling_for_ the_Future_July_23_2015.pdf

Wildcat, D. R. (2001). Prelude to a dialogue. In V. Deloria \& D. R. Wildcat (Eds.), Power and place: Indian education in America (pp. vii). Fulcrum Resources. 